Understanding the International Economic Order Robert Gilpin

This book is the eagerly awaited successor to Robert Gilpin's The Political Economy of International Relations. It offers a masterful survey of the approaches that have been used to understand international economic relations and the problems faced in the new economy.

"In a book that is deeply thought as well as deeply researched and carefully argued, Gilpin has produced a landmark study."

-Robert Jervis, Columbia University

Paper \$18.95 ISBN 0-691-08677-X Cloth \$59.50 ISBN 0-691-08676-1

\title{
Diplomacy of Conscience
}

Amnesty International and Changing Human Rights Norms Ann Marie Clark

A small group founded Amnesty International in 1961 to translate human rights principles into action. Drawing on primary interviews and archival research, Ann Marie Clark applies insights from the successes of Amnesty International to build a theory of the autonomous role of nongovernmental actors in the emergence of international norms pitting moral imperatives against state sovereignty.

Paper \$16.95 ISBN 0-691-05743-5 Cloth \$39.50 ISBN 0-691-05742-7
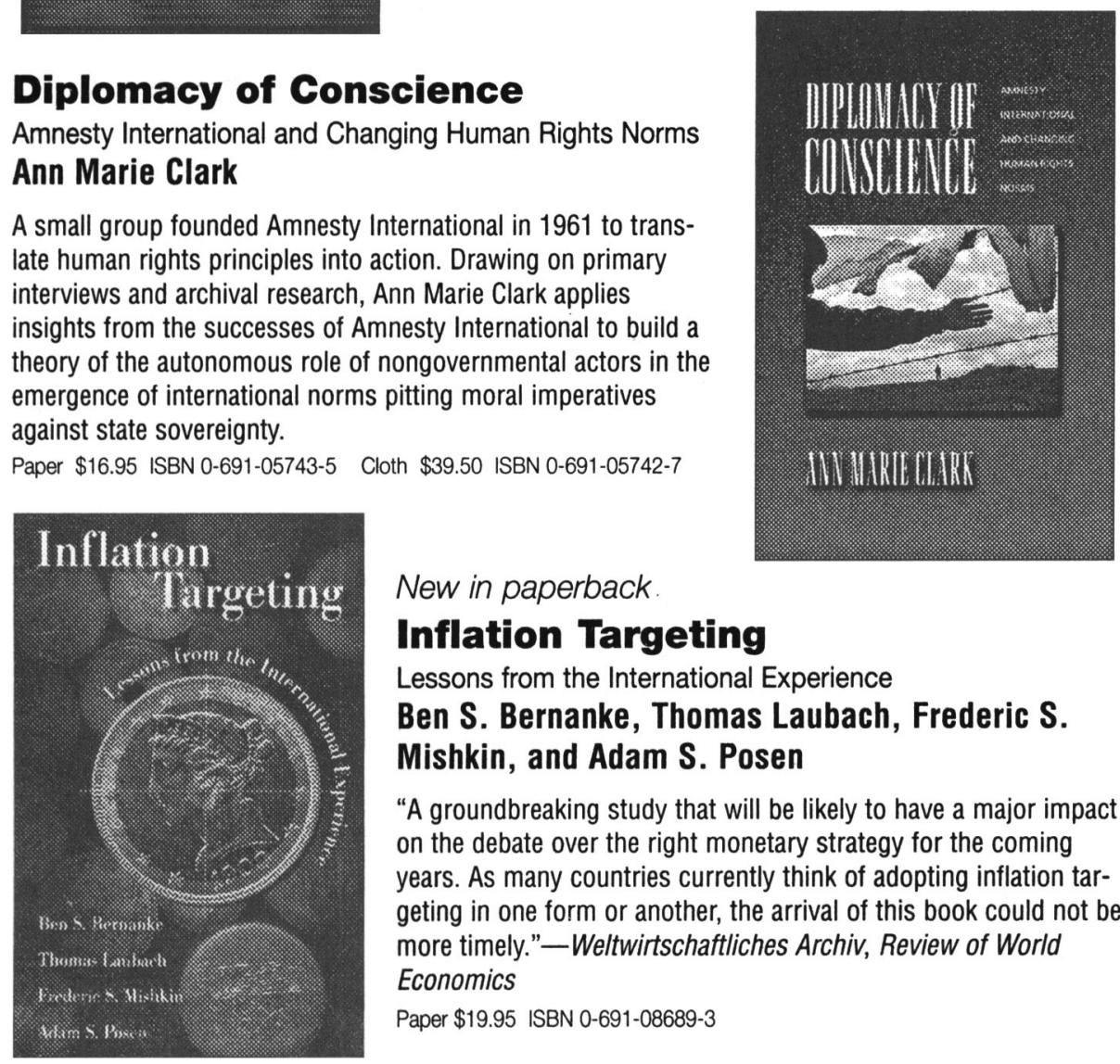

New in paperback

\section{Inflation Targeting}

Lessons from the International Experience

Ben S. Bernanke, Thomas Laubach, Frederic S. Mishkin, and Adam S. Posen

"A groundbreaking study that will be likely to have a major impact on the debate over the right monetary strategy for the coming years. As many countries currently think of adopting inflation targeting in one form or another, the arrival of this book could not be more timely."-Weltwirtschaftliches Archiv, Review of World Economics

Paper $\$ 19.95$ ISBN 0-691-08689-3

\section{Фळ Princeton University Press}


Legalization and

\section{World Politics}

edited by Judith L. Goldstein, Miles Kahler,

Robert O. Keohane, and Anne-Marie Slaughter

An exploration of the Intersection of international law and world politics from the viewpoints of the two disciplines.

International Organization Special Issues 336 pp. $\$ 24.95$ paper

\section{The Health}

\section{of Nations}

Infectious Disease,

Environmental Change, and

Their Effects on National

Securtty and Development

Andrew T. Price-Smith

"Will be known as the book on the political economy of disease for some time to come." - Dennis Pirages, University of Maryland

232 pp., 1 illus. \$22.95 paper

\section{International}

\section{Relations and Global} Climate Change

edited by Urs Luterbacher and Detlef F. Sprinz

-[G]athers together a variety of approaches from the field of international relations to explore the development of the climate change regime. It fills a niche that surprisingly no other book has filled." - Marvin Soroos, Nor th Carolina State University

Global Environmental Accord: Strategies for Sustainability and Institutional Innovation series

328 pp., 7 illus. \$25 paper

Keeping the Edge

\section{Managing Defense}

for the Future

edited by Ashton B. Carter

and John P. White

"I truly found this book the best work on our current military problems and the way ahead."

- General Anthony Zinni (Ret.).

Commander-in-Chief of U.S. Central Command, 1997-2000

BCSIA Studies in International Security 352 pp. $\$ 24.95$ paper
Environmental Leadership in Developing

\section{Countries}

Transnational Relatlons and Blodiversity Policy in Costa Rlca and Bollvia

Paul F. Steinberg

-This is an unusually interesting approach to a subject that receives too little attention and a notable account of a largely undisclosed history. It will be a very significant contribution to the field."

- Michael Redclift, King's College London

American and Comparative Environmental Policy series 272 pp., 32 illus. \$24.95 paper

\section{Environmental} Regime

\section{Effectiveness}

\section{Confronting Theory}

with Evidence

Edward L. Miles, Arild Underdal,

Steinar Andresen,

Jergen Wettestad,

Jon Birger Skjærseth,

and Elaine M. Carlin

"This important book breaks new ground in the study of international institutions and develops arguments that will undoubtedly stimulate additional research."

- Oran R. Young, Dartmouth College

Global Environmental Accord: Strategies for Sustainability and Institutional Innovation series

512 DD., 10 illus. \$29.95 paper

\section{What the}

\section{Future Holds}

Insights from Social Sclence edited by Richard N. Cooper and Richard Layard

Social scientists from various disciplines discuss and offer predictions about the future. 288 pp., 7 illus. $\$ 29.95$ 


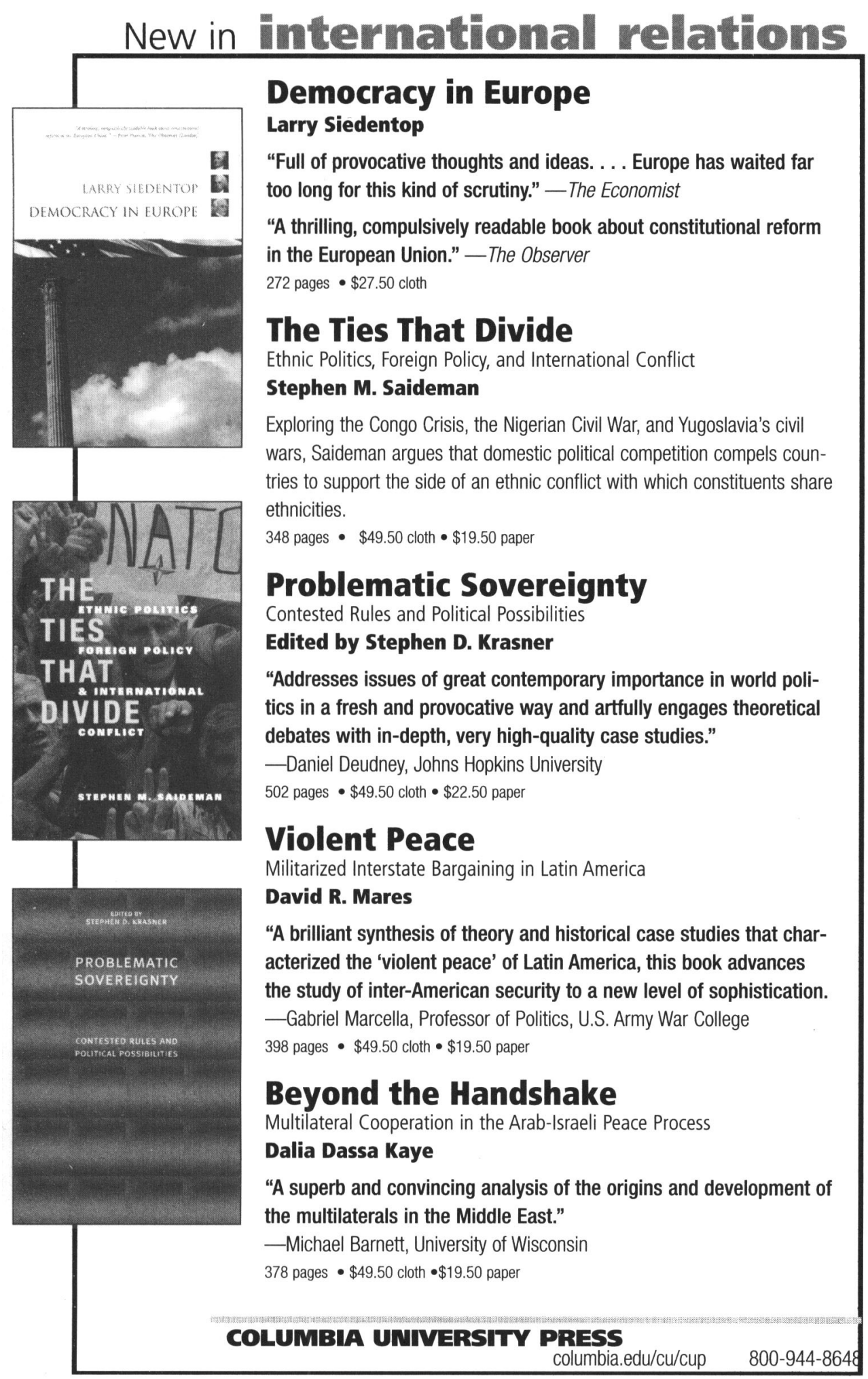




\section{Keep informed with \\ International Organization}

Whether your main interest is in international relations, business, or finance, you can't afford to be without the timely, authoritative, and influential articles in INTERNATIONAL ORGANIZATION. Order your personal subscription today and join the experts in universities, embassies, corporations, and international think tanks who must read INTERNATIONAL ORGANIZATION to keep informed of today's shifting alliances and international market activity. The full text of 10 is now available online from The MIT Press. For an additional $\$ 50$ annual fee, individual subscribers can now access 10 back volumes 1 to 49 available online from JSTOR.

_ This is a new subscription.

_ This is a renewal. My account number is (see label)

Your subscription will begin with Vol. 55, No. 1 (Winter 2001).

_ This is a gift. (Please attach recipient's name/address as well as your own.)

2001 RATES (check one)

$$
\text { U.S. }
$$

- Print E Electronic -

Canada* All Other Countries

Individual

Institution

Student**/Retired

-Price reflects $7 \%$ GST.

Access Fee to JSTOR
- $\$ 44.94 \quad \$ 62$

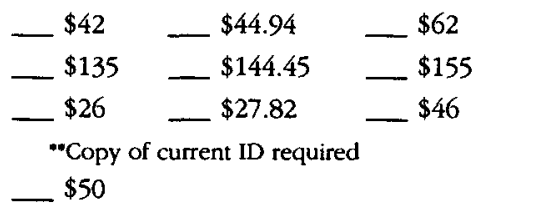

- Electronic Only -

U.S. E Foretgn Canada*

- $\$ 38-\$ 40.66$

ـ $\$ 122 \_\$ 130.54$

-\$23 $\quad \$ 24.61$

\section{Prepayment required}

Check or money order enclosed, payable to International Organization.

(check must be drawn against a U.S. bank in U.S. funds)

Charge to my MasterCard VISA AmEx

Account No. Expiration Date

Signature Today's Date

Print cardholder's name

Send the subscription to: (please print clearly)

Name Daytime phone

Company/Dept. E-mail

Address

Ciry/State/Province/Zip/Country IOBM01

For ordering information on back issues, contact:

Circulation Department

MIT Press Journals

Five Cambridge Center

Cambridge, MA 02142

Tel: 617-253-2889

Fax: 617-577-1545

journals-orders mit.edu

http://mitpress.mit.edu/IO
To subscribe, send this form with your payment to the Circulation Department at the address at left or order by pbone, fax or email. 


\section{International Organization}

Volume 55 Number 3 Summer 2001

International Organization (ISSN 0020-8183) is published quarterly (winter, spring, summer, and autumn) by The MIT Press, Five Cambridge Center, Cambridge, MA 02142-1407. An electronic, full-text version of IO is available from the MIT Press. Subscriptions and address changes should be addressed to MIT Press Journals, Five Cambridge Center, Cambridge, MA 02142-1407; telephone (617) 253-2889; fax (617) 577-1545; e-mail: journalsorders@mit.edu. Subscriptions are on a volume year basis. Subscription rates: Electronic only-Individuals $\$ 38.00$, Students/retired $\$ 23.00$. Institutions $\$ 122.00$. Canadians add $7 \%$ GST. Print and Electronic-Individuals \$42.00, Students/retired \$26.00. Institutions $\$ 135.00$. Outside the U.S. and Canada add $\$ 20.00$ for postage and handling. Canadians add the 7\% GST. Current issues are $\$ 36.00$. Back issue rates: Individuals $\$ 18.00$, Institutions $\$ 36.00$. Outside the U.S. and Canada add $\$ 5.00$ for postage and handling. Canadians add $7 \%$ GST. For an additional $\$ 50.00$ annual fee, individual subscribers can access IO back volumes $1-49$, available online from JSTOR. Claims for missing issues will be honored free of charge if made within three months after the publication date of the issue. Claims may be submitted to: journals-claims@mit.edu. Prices subject to change without notice. Postmaster: Send address changes to International Organization, Five Cambridge Center, Cambridge, MA 02142-1407. Periodicals postage paid at Boston and additional mailing offices.

International Organization is abstracted or indexed in the following: Academic Abstracts, ABC Pol Sci, America: History and Life, Communication Abstracts, Current Contents/Social \& Behavioral Sciences, Current Law Index, Deep Sea Research \& Oceanographic Abstracts, Energy Research Abstracts, Expanded Academic Index, Future Survey, Historical Abstracts, Human Rights Internet Reporter, INIS Atomindex, Index of Economics Articles, International Bibliography of Economics (also in IBSS), International Bibliography of Periodical Literature, International Bibliography of the Social Sciences/Political Science, International Labour Documentation, International Political Science Abstracts, Journal of Economic Literature, Key to Economic Science, Legal Research Index, Magazine Index (Information Access Company), Middle East: Abstracts and Index, Public Affairs Information Service/ PAIS, Recently Published Articles, Rural Recreation and Tourism, SCIMP (Selective Cooperative Index of Management Periodicals), Social Sciences Citation Index, Social Sciences Index, Social Science Source, Sociological Abstracts, World Agricultural Economics \& Rural Sociology Abstracts.

Advertising and mailing list rental: Please write to Marketing Department, MIT Press Journals, Five Cambridge Center, Cambridge, MA 02142-1407 USA, or telephone (617) 253-2866, fax (617) 258-5028, e-mail: journals-info@mit.edu.

Rights and permissions: All inquiries concerning rights and permissions should be sent to Subsidiary Rights Manager, MIT Press Journals, Five Cambridge Center, Cambridge MA 02142-1407; telephone (617) 253-2864; fax (617) 258-5028; e-mail: journalsrights@mit.edu. Permission to photocopy articles for internal or personal use or the internal or personal use of specific clients is granted by The IO Foundation and the Massachusetts Institute of Technology for libraries and other users registered with the Copyright Clearance Center (CCC), provided that the fee of $\$ 8.00$ per copy is paid directly to CCC, 222 Rosewood Drive, Danvers, MA 01923. The fee code for users of the Transactional Reporting Services is $0020-8183 / 01 \$ 8.00$. For those organizations that have been granted a photocopy license with $\mathrm{CCC}$, a separate system of payment has been arranged. 


\section{A Journal of \\ Political and \\ Economic Affairs \\ Edited at the University of California, San Diego \\ Published by The MIT Press}

